\title{
EDITORIAL
}

\section{PERIÓDICOS CIENTÍFICOS E A CIÊNCIA DO DIREITO NO BRASIL}

Este ano de 2017 é paradoxal para o conhecimento científico. Por um lado, é o pior ano para as políticas públicas de fomento à ciência e tecnologia. Pouco mais do que $\mathrm{R} \$ 5$ bilhões devem ser investidos nesse campo, o que representa um valor de 35\% do que costumava a ser aplicado em anos anteriores. Mais ainda, é o ano em que pesquisadores fizeram uma inédita Marcha pela Ciência. Desta vez não pelo emprego e salários melhores nessa área, mas pelo respeito ao conhecimento baseado em evidências e pela utilidade desse tipo de conhecimento para a tomada de decisões em qualquer área. É muito estranho que, repentinamente, em 2017, pesquisadores de mais de 600 cidades em todo o mundo tiveram de se levantar para dizer algo tão simples: que o conhecimento científico é para ser levado a sério!

Por outro lado, temos bons motivos para comemorar, particularmente na Pós-graduação em Direito no Brasil. A divulgação dos resultados da avaliação realizada pelo Comitê Qualis, da Capes, revelou que a Pós-graduação ingressou, decididamente, no território editoração científica: passamos a ter um número muito expressivo de periódicos que cumprem os requisitos dos mais elevados estratos de qualidade editorial, ou seja, B1, A2 e A1.

Neste momento (28.04.17) ainda não sabemos, exatamente, quantos são. Mas sabemos que hoje a pós-graduação em direito tem periódicos de qualidade superior em quase todas as regiões, na maioria dos Estados, em Programas tradicionais e também em jovens programas. Há mais e melhores periódicos científicos do que em qualquer outro momento da Pós-Graduação Stricto Sensu em Direito do Brasil. Isso indica que a qualidade da editoração científicaem direito melhorou exponencialmente e por critérios mensuráveis. É um passo importantíssimo e precisa ser comemorado.

Também quer dizer que a produção intelectual no campo do direito está passando, e vai continuar a passar, por uma revisão substantiva. A publicação em periódicos científicos de elevado estrato na lista do Qualis-Capes passou a ser o mais importante referencial de qualidade da produção científica dos mestrados e doutorados da área do direito. Isso não é nada desprezível, enquanto mudança. A área do direito tem uma tradição de saber doutrinário e de publicação em livros (grandes livros, muitos tomos...). E agora está bem claro que isso está mudando.

Nota-se, de início, que é muito grande o número de doutores em direito que se tornaram avaliadores de periódicos. Isso quer dizer que aumentou muitíssimo a colaboração entre programas de pós-graduação e que a avaliação por pares está sendo desmistificada. Avaliar e ser avaliado passou a ser uma regra boa.

Além disso, em vez de grandes tratados e longos comentários ou manuais em forma de cursos, aumentou significativamente o número de doutores em direito que publica, apenas, trabalhos menores, muito especializados. Em contrapartida, como a qualidade dos periódicos subiu muito, aumentou também a qualidade científica das produções, dado que Editores passaram a ter preferência não só por trabalhos bem escritos, mas por textos que representam o resultado de pesquisas relevantes e com potencial de citação. Quem está acompanhando esse movimento, pode ver ainda mais coisas: a migração 
das produções em periódicos para o formato digital aumentou a visibilidade das revistas científicas e dos Programas que sustentam esses periódicos.

Muito novo também, e importante, é a melhor disposição de editores de periódicos científicos de conversar, de compartilhar experiências (boas e más), e de pensar o futuro da editoração científica em direito e o modo como se faz ciência do direito no Brasil. Grupos de diálogos entre editores estão se consolidando e gerando uma interação muito crítica e produtiva. Editores estão notando que, nesse processo de mudanças, são os atores mais expostos aos avanços e abusos das boas práticas científicas, além disso, estão concluindo que são as revistas e os Editores que podem implementar mudanças que repercutem na melhor qualidade da ciência do direito. Editores se dão conta de que representam seus leitores e que não podem abandoná-los, pois revistas bem qualificadas dependem de leitores e de citações. Tudo isso está acontecendo. E é bom que seja agora.

É que este também é um momento ímpar de crise, como bem aponta o editorial do Prof. Dr. Eduardo Gomes, publicado neste número. É um momento ímpar, também, de visibilidade política dos profissionais do direito, não só pela hiperexposição midiática dos tribunais, como também pela judicialização massiva da política. É um momento de crise grave dos fundamentos da segurança jurídica, do Rule of Law, da representação democrática, do significado de desenvolvimento, dos padrões produtivos, de trabalho de proteção da renda, e do consumo; da relação com os estrangeiros, da tolerância religiosa e social; das formas de comunicação e de exposição da privacidade. É um momento como poucos, de extrema necessidade de pesquisa séria e de produção de conhecimento relevante sobre o Brasil, os brasileiros, os problemas atuais, as mudanças necessárias, as tendências dos acontecimentos. É muito bom, portanto, que a editoração científica tenha dado esse salto qualitativo neste momento.

Todos os editores conhecem os desafios desta nova fase: consolidar boas práticas editoriais, aprimorar o diálogo para resolver problemas de desonestidade na pesquisa científica e impulsionar a disseminação do conhecimento de alta qualidade. Por isso, documentos sobre boas práticas científicas, como os recomendados pela Fapesp ${ }^{1}$, pelo $\mathrm{CNPq}^{2}$ e até mesmo por organizações internacionais, como os parâmetros do Guia do International Committee of Medical Journal Editors (ICMJE) passarão a ser mais discutidos e adotados pelas boas revistas da área do direito.

A EJJL saúda, assim, todos os editores científicos da área do direito que se dedicaram a essas melhorias no último quadriênio, e saúda, particularmente, as revistas que hoje estão nos mais altos estratos do Qualis-CAPES. Aos leitores deste número 1 de 2017, a Comissão Editorial da EJJL , agora no grupo das Revistas A1, renova seu compromisso de firme propósito de continuar a publicar apenas as melhores pesquisas que receber e observar estritamente os cânones internacionais de boas práticas.

Carlos Luiz Strapazzon, Editor-Chefe, EJJL | Unoesc

\footnotetext{
Documentos de interesse relacionados com Boas Práticas na Pesquisa Científica, disponível em: <http://www.fapesp. br/6574 > . Acesso em: 28 abr. 2017.

2 Diretrizes básicas para a integridade na atividade científica, disponível em: < http://cnpq.br/diretrizes. Acesso em: 28 abr. 2017.

<http://editora.unoesc.edu.br/index.php/espacojuridico/index >.
} 